\title{
NILAI-NILAI PRIBADI KONSELOR DALAM PRIBADI SEORANG KIAI
}

\author{
Oleh: \\ Hanik Mufaridah \\ Universitas Ibrahimy Sukorejo Situbondo \\ hany_kanikom@yahoo.com
}

\begin{abstract}
:
Values include individual attitudes, as a standard of action and belief. And among the competencies that must be possessed by a counselor is personality competence. The purpose of this study is to find out and describe the similarities and differences in the counselor's personal values contained in Carl Rogers' theory of person centered therapy with the personal values contained in Kiai As'ad. The results show that the similarities are respecting individuals and humility; psychological knowledge and expert communication; harmony or authenticity and firmness hold the principle; and unconditional and sincere positive attention in charity and struggle. While the difference is Carl Rogers (objectivity, self-understanding, and accurate empathic understanding) and Kiai As'ad (zuhud and modest, fighters, time discipline and istiqomah, independent living and maintaining cleanliness, fond of building for the interests of religion and nation, attaching importance to interests people, and affection.
\end{abstract}

Key Words: Kebahagiaan, Keharmonisan, Cinta, Kematangan, Intensitas Komunikasi, Rumah Tangga

\section{A. Pendahuluan}

Bimbingan dan konseling berasal dari dua kata, yaitu bimbingan (guidance) dan konseling (counseling). Konseling merupakan salah satu metode dari bimbingan, sehingga pengertian bimbingan lebih luas daripada koneling. Oleh karena itu, konseling merupakan bimbingan, tetapi tidak semua bimbingan merupakan kegiatan konseling. ${ }^{1}$ Bimbingan adalah proses pemberian bantuan yang dilakukan oleh seorang ahli kepada seorang atau beberapa orang individu (anak-anak, remaja, maupun dewasa), yang bertujuan agar orang yang dibimbing dapat mandiri dan mengembangkan kemampuannya sendiri, dengan 1989), 6 .

${ }^{1}$ Bimo Walgito, Bimbingan dan Penyuluhan di Sekolah (Yogyakarta: Andi Offset,

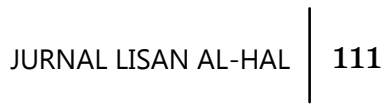


memanfaatkan kekuatan individu dan sarana yang ada dan dapat dikembangkan berdasarkan norma-norma yang berlaku. ${ }^{2}$ Sejalan dengan itu, Anas Salahudin mengemukakan bahwa bimbingan merupakan proses pemberian bantuan yang dilakukan oleh seorang ahli kepada seorang/beberapa orang individu dalam hal memahami diri sendir, menghubungkan pemahaman tentang dirinya sendiri dengan lingkungan, memilih, menentukan, dan menyusun rencana sesuai dengan konsep dirinya dan tuntutan lingkungan berdasarkan norma-norma yang berlaku. $^{3}$

Sedangkan konseling merupakan proses pemberian bantuan yang dilakukan oleh seorang ahli kepada individu yang sedang mengalami suatu masalah melalui serangkaian wawancara konseling yang bermuara pada teratasinya masalah yang dihadapi individu tersebut. ${ }^{4}$ Berdasarkan pengertian bimbingan dan konseling yang telah dikemukakan oleh para ahli tersebut, dapat dinyatakan bahwa bimbingan dan konseling merupakan suatu proses pemberian bantuan kepada individu secara berkelanjutan dan sistematis, yang dilakukan oleh seorang ahli yang telah mendapatkan latihan khusus, dengan tujuan agar individu dapat memahami dirinya, lingkungannya, serta dapat mengarahkan dan menyesuaikan diri dengan lingkungan untuk mengembangkan potensi diri secara optimal demi kesejahteraan diri dan masyarakat.

Lebih lanjutnya, berdasarkan PP Nomor 28 Tahun 1990 pada Bab X Pasal 25 dan PP Nomor 29 Tahun 1990 pada Bab X Pasal 27, ditegaskan dalam Ayat bahwa "bimbingan merupakan bantuan yang diberikan kepada siswa dalam rangka upaya menemukan pribadi, mengenal lingkungan dan merencanakan masa depan, dan bimbingan diberikan oleh guru pembimbing (konselor)". ${ }^{5}$ Di sisi lain, secara eksplisit ditetapkannya "konselor" sebagai salah satu tenaga kependidikan dalam Undang-Undang Republik Indonesia Nomor 20 Tahun 2003 tentang Sistem Pendidikan Nasional. Pada Bab I Pasal 1 Ayat (4) dinyatakan bahwa "pendidik adalah tenaga kependidikan yang berkualifikasi sebagai guru, dosen, konselor, pamong belajar, widyaiswara, tutor, instruktur, fasilitator, dan sebutan lain yang sesuai dengan kekhususannya, serta berpartisipasi dalam

\footnotetext{
2004), 99.

${ }^{2}$ Prayitno \& Erman Amti, Dasar-dasar Bimbingan Konseling (Jakarta: Rineka Cipta,

${ }^{3}$ Anas Salahudin, Bimbingan \& Konseling (Bandung: CV Pustaka Setia, 2012), 15.

${ }^{4}$ Prayitno \& Amti, Dasar-dasar Bimbingan, 105.

${ }^{5}$ Dewa Ketut Sukardi \& Nila Kusmawati, Proses Bimbingan dan Konseling di Sekolah (Jakarta: Rineka Cipta, 2008), 20-21.
}

112 JURNAL LISAN AL-HAL 
penyelenggaraan pendidikan. ${ }^{6}$

Konselor merupakan tenaga pendidik yang memiliki keahlian dan kompetensi untuk melaksanakan tugas bimbingan di sekolah. Dalam menjalankan tugas dan fungsinya di sekolah, konselor dituntut untuk memiliki kompetensi-kompetensi pendukung kinerja konselor agar menjadi tenaga profesional yang ahli dalam bidangnya. Dalam "Standar Kompetensi Konselor", terdapat empat kompetensi yang harus dimiliki oleh seorang konselor. Keempat kompetensi tersebut yaitu; (1) memahami secara mendalam konseli yang hendak dilayani; (2) menguasi landasan teoretik bimbingan dan konseling; (3) menyelenggarakan bimbingan dan konseling yang memandirikan; dan (4) mengembangkan pribadi dan profesionalitas secara berkelnjutan. ${ }^{7} \mathrm{Hal}$ ini sejalan dengan Undang-undang nomor 27 tahun 2008 tentang standar kualifikasi akademik dan kompetensi konselor yang menyebutkan bahwa di antara kompetensi yang harus dimiliki oleh konselor adalah kompetensi kepribadian. ${ }^{8}$

Di antara kompetensi kepribadian yang harus dimiliki konselor yaitu beriman dan bertakwa kepada Tuhan Yang Maha Esa dan menunjukkan integritas dan stabilitas kepribadian yang kuat. Integritas dan stabilitas kepribadian tersebut dapat tercermin dalam perilaku yang terpuji, emosi yang stabil, peka, bersikap empati, menghormati keragaman dan perubahan, toleransi tinggi, bertindak secara cerdas, kreatif, inovatif dan produktif, bersemangat, berdisiplin, mandiri, berpenampilan menarik dan menyenangkan, serta berkomunikasi secara efektif. ${ }^{9}$ Selain itu, Prayitno \& Erman Amti mengungkapkan sepuluh kapribadian bagi seorang guru pembimbing (konselor), yaitu perangai, emosi, mandiri, bobot, integritas, mawas, berani, inteligensi, nalar dan gagasan. ${ }^{10}$

Kepribadian konselor atau yang biasa dikaitkan dengan kualitas pribadi konselor menurut Willis dalam Anas Salahudin yakni semua kriteria unggulan, termasuk pribadi, pengetahuan, wawasan, keterampilan dan nilai-nilai yang dimilikinya, yang akan memudahkannya dalam

${ }^{6}$ Ibid, 21.

${ }^{7}$ Departemen Pendidikan Nasional, Penataan Pendidikan Profesional Konselor dan Layanan Bimbingan dan Konseling dalam Jalur Pendidikan Formal (Jakarta: Dirjendikti, 2008), 143-146.

8 Akhmad Sudrajat, "Kualifikasi dan Kompetensi Konselor - Permendiknas No.27 Tahun 2008", dalam https://akhmadsudrajat.wordpress.com/2008/12/16/kualifikasi-dankompetensi-konselor/, (3 Desember 2017), 1.

${ }^{9}$ Departemen Pendidikan Nasional, Penataan Pendidikan, 145.

${ }^{10}$ Prayitno \& Amti, Dasar-dasar Bimbingan, 9. 
menjalankan proses konseling sehingga mencapai tujuan dengan berhasil (efektif). ${ }^{11}$ Kajian mengenai kepribadian konselor selama ini lebih berpusat pada teori-teori kepribadian yang berasal dari Barat, khususnya Amerika Serikat. Namun tidak semua teori yang berasal dari Barat tersebut dapat digunakan oleh konselor di Indonesia. Hal ini dikarenakan pertimbangan beberapa aspek penting, seperti nilai spiritual, nilai adat, nilai sopan santuan, dan lain sebagianya. Di Indonesia dengan penduduk yang sebagian besar memeluk agama Islam, nilai-nilai tersebut sangatlah penting untuk dipertimbangkan. Dimana tokoh Kiai merupakan salah satu panutan bagi masyarakat yang beragama Islam khususnya.

Nilai merupakan bagian yang amat penting dari pengalaman yang mempengaruhi perilaku individu. Nilai meliputi sikap individu, sebagai standar tindakan dan keyakinan (belief). Nilai dapat menyatakan pada orang lain apa yang penting bagi individu dan menuntun individu dalam mengambil keputusan. ${ }^{12}$ Nilai menjadi pedoman atau prinsip umum yang memandu tindakan, tentang apa yang harus dilakukan dan kapan melakukannya. Masyarakat yang berbeda dapat sama-sama menganggap prestasi sebagai sesuatu yang bernilai, namun dapat berbeda dalam hal apa yang harus diraih, bagaimana meraihnya, dan kapan perlu meraih prestasi tersebut.

Berikut dua konsep nilai yang sering dijadikan rujukan dalam mengngkap nilai, yakni konsep nilai Rokeach dan konsep nilai Schwartz. Rokeach mengungkapkan bahwa nilai bersifat stabil, karena nilai bukan merupakan evaluasi terhadap tindakan atau objek spesifik, melainkan lebih mempresentasikan kriteria normatif yang digunakn untuk membuat evaluasi. Selain itu, nilai dianggap sebagai daya yang dapat menggerakkan perilaku, sehingga nilai menjadi istrumen untuk menjelaskan perilaku individu. Sedangkan Schwartz mengungkapkan bahwa nilai mempresentasikan respon individu secara sadar terhadap tiga kebutuhan dasar, yakni kebutuhan fisiologis, interaksi sosial, dan institusi sosial yang menjamin keberlangsungan hidup dan kesejahteraan kelompok. ${ }^{13}$

Nilai sebagai bagian integral dari perilaku sosial dalam suatu budaya yang bersifat religius, spiritual, dan mengatur. Budaya merupakan warisan sekaligus masa depan yang menjadi dasar bagi individu dan bangsa untuk membentuk identitasnya. Budaya adalah sistem nilai dan

${ }^{11}$ Anas Salahudin, Bimbingan dan Konseling (Bandung: Pustaka Setia, 2010), 21.

12 Sri Lestari, Psikologi Keluarga: Penanaman Nilai dan Penanganan Konflik dalam Keluarga (Jakarta: Kencana, 2012), 77.

${ }^{13}$ Ibid, 71-75.

114 JURNAL LISAN AL-HAL 
kepercayaan yang dipegang secara bersama oleh beberapa orang dan memberikan perasaan menjadi bagian dari kelompok atau rasa identitas. ${ }^{14}$ Oleh karena itu, penelitian ini ingin mengkaji nilai pribadi yang ada di dalam pribadi Kiai sebagai nilai pribadi konselor Indonesia. Nilai pribadi konselor yang akan dikaji yakni pribadi konselor dalam teori person centered therapy yang dicetuskan oleh Carl Rogers dengan pribadi seorang kiai kharismatik yakni Kiai As'ad Syamsul Arifin, merupakan salah seorang kiai yang berasal dari Sukorejo Situbondo yang memperoleh gelar pahlawan nasional.

Konsep person centered therapy dalam memandang kepribadian manusia, menurut Rogers terdiri dari tiga aspek, yaitu pertama, organisme phenomenal field, dan self concept. Organisme merupakan individu itu sendiri, mencakup aspek fisik maupun psikologis. Sedangkan phenomenal filed yaitu pengalaman-pengalaman hidup yang bermakna secara psikologis bagi individu, berupa pengetahuan, pengasuhan orang tua dan hubungan pertemanan. Dan yang terakhir self concept yakni interaksi organisme atau fisik individu sendiri dengan phenomenal field yang akan membentuk ("I/me"/saya).

Teori person centered berlandaskan suatu filosofi tentang bagaimana manusia menyusun dirinya sendiri menurut persepsipersepsinya akan kenyataan. Orang termotivasi untuk mengaktualisasikan diri dalam kenyataan yang dipersepsinya. Oleh karena itu, diperlukan adanya konsep diri ataupun mempersepsi diri dalam menghadapi masalah yang dihadapi tersebut, agar mencapai aktualisasi diri yang seseorang miliki. Manusia memiliki kesanggupan untuk mengarahkan diri dan melakukan perubahan pribadi yang konstruktif.

Menurut Corey, pendekatan person centered dibangun atas dua hipotesis dasar, yaitu (1) setiap orang memiliki kapasitas untuk memahami keadaan yang menyebabkan ketidakbahagiaan dan mengatur kembali kehidupannya menjadi lebih baik, dan (2) kemampuan seseorang untuk menghadapi keadaan ini dapat terjadi dan ditingkatkan jika konselor menciptakan kehangatan, penerimaan, dan dapat memahami relasi (proses konseling) yang sedang dibangun. ${ }^{15}$ Dalam pendekatan person centered therapy, seseorang dilihat sebagai sosok yang bertindak untuk memenuhi kebutuhan pokokonya, yakni kebutuhan untuk (1995), 75 .

${ }^{14}$ N.R. Shet, "Values in Search of Identity", Journal of Human Values, Vol. 1, No. 1

${ }^{15}$ John Mcloeod, Pengantar Konseling: Teori dan Studi Kasus Ed.3, Cet.3 (Jakarta: Kencana, 2010), 263. 
aktualisasi diri dan kebutuhan untuk dicintai dan dihargai oleh orang lain.

Teori berfokus pribadi (person centered therapy) didasarkan pada kepercayaan fundamental, bahwa manusia itu pada intinya terpercaya, sosial dan kreatif. Ekspresi praktis kepercayaan tersebut adalah kemauan terapis untuk menggosongkan posisi keahliannya dan justru bekerja untuk memampukan klien menyadari sumber dayanya sendiri dan pemahaman dirinya. Konseling berfokus pribadi menekankan pentingnya pengalaman individual, pada intinya terapi ini adalah teori relasi, mengakui saling ketergantungan dengan cara memberikan jalan menuju komunikasi yang dalam dan bisa diterima dengan orang lain. ${ }^{16}$

Prinsip-prinsip yang digunakan dalam pelayanan bimbingan dan konseling bersumber dari kajian filosofis, hasil-hasil penelitian dan pengalaman praktis tentang hakikat manusia, perkembangan dan kehidupan dalam konteks sosial budaya, pengertian, tujuan fungsi, dan proses penyelenggaraan bimbingan dan konseling. ${ }^{17}$ Sejalan dengan itu, konsep konseling Islam sesungguhnya telah ada sejak zaman Rasulullah, banyak sumber yang menunjukkan bahwa Nabi Muhammad SAW telah mempraktikkan prinsip-prinsip konseling Islam secara sempurna, sehingga hanya dalam kurun waktu 23 tahun Rasulullah dapat merubah suku bangsa yang mulanya jahilliyah menjadi umat yang bertauhid, berakhlak mulia dan berbudaya tinggi. Namun secara istilah konseling Islam agaknya baru muncul beberapa dekade belakang ini, sehingga konseling Islam masih menjadi pembahasan baru dalam bidang konseling.

Bagi masyarakat Indonesia yang mayoritas penduduknya beragama Islam, nampaknya konseling Islam dapat menjadi satu alternatif pendidikan yang dapat diterapkan di tengah-tengah masyarakat. Mengingat konseling Islam sesungguhnya ada sejak zaman Rasulullah dan kompleksnya kehidupan masyarakat dari berbagai bidang, sehingga konseling Islam menyentuh segala aspek kehidupan manusia. Bimbingan dan konseling Islam hadir dalam masyarakat sebagai sarana dan wahana yang sangat baik untuk pembinaan sumber daya manusia. Bimbingan konseling berperan dalam mencarikan jalan keluar dari setiap kesulitan yang dihadapi masyarakat dalam usaha mengembangkan potensinya.

Bimbingan dan konseling Islam adalah upaya membantu individu belajar mengembangkan fitrah iman atau kembali kepada fitrah iman, dengan cara memberdayakan (enpowering), fitrah-fitrah (jasmani, rohani, 2011), 301

${ }^{16}$ Stephen Palmer (Ed), Konseling dan Psikoterapi (Yogyakarta: Pustaka Pelajar,

${ }^{17}$ Ibid, 128.

116 JURNAL LISAN AL-HAL 
nafs, dan iman) mempelajari dan melaksanakan tuntutan Allah dan RasulNya, agar fitrah-fitrah yang ada pada individu berkembang dan berfungsi dengan baik dan benar. ${ }^{18}$ Konseling Islam adalah aktivitas yang bersifat "membantu", dikatakan membantu karena pada hakikatnya individu sendirilah yang perlu hidup sesuai tuntunan Islam (al-Qur'an dan sunnah Rasul-Nya). Pada akhirnya diharapkan agar individu selamat dan memperoleh kebahagiaan yang sejati di dunia dan akhirat.

Pihak yang membantu dalam bimbingan dan konseling Islam adalah seorang guru pembimbing (konselor), yaitu seorang mukmin yang memiliki pemahaman yang mendalam tentang tuntutan Allah dan menaatinya. Bantuan itu terutama berbentuk pemberian dorongan dan pendampingan dalam memahami dan mengamalkan syariat Islam. ${ }^{19}$ Oleh karena itu, dari pembahasan sebelumnya, maka akan dilakukan pengkajian nilai-nilai pribadi konselor berdasarkan teori konseling berpusat pada individu (person centered therapy) yang dikhususkan pada pembahasan pribadi konselor dengan konseling Islam yang dikhususkan pada pribadi Kiai, yakni sosok figur sentral yang sikap sehari-harinya banyak mempengaruhi kepribadian murid-muridnya.

\section{B. Metode Penelitian}

Penelitian ini menggunakan riset kepustakaan (library riset). Dengan tujuan untuk menemukan jawaban dari analisis kedua teori tersebut, yang berupa persamaan-persamaan dan perbedaan-perbedaan dalam nilai-nilai pribadi konselor berdasar teori person centered therapy Carl Rogers dan pribadi Kiai As'ad. Tidak hanya itu peneliti juga menggunakan jenis penelitian kualitatif. Sebab jenis data yang digali berupa kata-kata atau kalimat-kalimat, dan ungkapan yang ada didalam buku person centered therapy Carl Rogers dan pribadi Kiai As'ad.

Tujuan penelitian ini adalah untuk: pertama, mengetahui dan mendeskripsikan persamaan nilai-nilai pribadi konselor yang terdapat di dalam teori person centered therapy Carl Rogers dengan nilai-nilai pribadi yang terdapat dalam diri Kiai As'ad dan Kedua, Mengetahui dan mendeskripsikan perbedaan nilai-nilai pribadi konselor yang terdapat di dalam teori person centered therapy Carl Rogers dengan nilai-nilai pribadi yang terdapat dalam diri Kiai As'ad.

${ }^{18}$ Anwar Sutoyo, Bimbingan dan Konseling Islami (Semarang: Widya Karya, 2008), 205

${ }^{19}$ Ibid, 22. 


\section{Pembahasan}

1. Temuan Konsep Mengenai Pribadi Konselor dalam Pribadi Kiai

Berdasar pendapat Brian Thorne dan Gerald Corey mengenai kepribadian terapis (konselor) dalam teori person centered therapy Carl Rogers, dapat dapat dikategorikan ke dalam tujuh nilai sikap atau kepribadian yaitu objektivitas, menghormati individu, pemahaman diri, pengetahuan psikologis, keselarasan atau kesejatian, perhatian positif tanpa syarat, dan pengertian empatik yang akurat. Sedangkan nilai pribadi dalam diri Kiai As'ad dapat diklasifikasi ke dalam 12 kategori, yaitu: zuhud dan sederhana, pejuang, teguh memegang prinsip, ikhlas dalam beramal/berjuang, rendah hati (tawadhu') dan tidak pendendam, disiplin waktu dan istiqomah, suka silaturrahim dan ziarah ke makam Sunan, hidup mandiri dan menjaga kebersihan, gemar membangun untuk kepentingan Agama dan Bangsa, sikap tawadhu dan ikhlas, piawai berkomunikasi, mementingkan kepentingan umat, dan kasih sayang.

Berdasarkan pemaparan dari masing-masing nilai kepribadian konselor yakni nilai kepribadian konselor menurut Carl Rogers dan nilai kepribadian dalam diri Kiai As'ad, maka di sini akan dibahas persamaan dan perbedaan dari kedua temuan tersebut.

\section{a. Persamaan Konsep Pribadi Konselor menurut Carl Rogers dan nilai Kepribadian dalam Diri Kiai As'ad}

Berdasar hasil telaah, persamaan konsep pribadi konselor menurut Carl Rogers dan nilai kepribadian dalam diri Kiai As'ad dapat dilihat pada tabel 1.1 dan berikut rinciannya:

Tabel 1.1. Persamaan Nilai-nilai Pribadi Konselor

\begin{tabular}{|c|l|l|}
\hline \multirow{2}{*}{ No. } & \multicolumn{1}{|c|}{ Nilia-nilai Pribadi Konselor } \\
\cline { 2 - 3 } & \multicolumn{1}{|c|}{ Carl Rogers } & \multicolumn{1}{c|}{ Kiai As'ad } \\
\hline 1. & Objektivitas & - \\
\hline 2. & Menghormati individu & Rendah hati \\
\hline 3. & Pemahaman diri & - \\
\hline 4. & Pengetahuan psikologis & Piawai berkomunikasi \\
\hline 5. & Keselarasan atau kesejatian & Teguh memegang prinsip \\
\hline 6. & Perhatian positif tanpa syarat & $\begin{array}{l}\text { Ikhlas dalam beramal atau } \\
\text { berjuang }\end{array}$ \\
\hline 7. & $\begin{array}{l}\text { Pengertian empatik yang } \\
\text { akurat }\end{array}$ & - \\
\hline
\end{tabular}


Pertama, Menghormati individu (Carl Rogers) dan rendah hati (tawadhu') dan tidak pendendam (Kiai As'ad). Menghormati individu bertujuan untuk melepaskan tanggung jawab utama ditangan klien sebagai individu yang akan menuju kebebasan diri/ kemandirian. Dan rendah hati Kiai As'ad terpancar melalui sikap beliau yang sangat menghormati guru, keluarga dan keturunannya. Selain itu, beliau juga berlapang dada dan tidak pendendam. Hal ini terbukti ketika suatu saat pernah berbeda pendapat dengan seorang penguasa daerah. Dalam berbagai kesempatan, beliau selalu dipojokkan dan dilecehkan. Dan suatu ketika penguasa tersebut jatuh sakit hingga opname. Mendengar hal tersebut, beliau langsung menjenguk dan mendo'akan agar segera sembuh dan dapat memimpin daerahnya kembali.

Kedua, Pengetahuan psikologis (Carl Rogers) dan piawai berkomunikasi (Kiai As'ad). Pengetahuan psikologis secara menyeluruh tentang prilaku manusia dan fisik, sosial dan penentu psikologis. Dan kepiawaian Kiai As'ad dalam berkomunikasi, merupakan tuntutan bagi seorang juru dakwah dalam melakukan beberapa pendekatan individual, yakni psikologis, antropologis dan sosiologis sasaran dakwahnya. Hal ini bertujuan agar ia mampu memberikan wawasan dan cara penyampaiannya lebih efektif dan efesien, sesuai dengan karakteristik orang tersebut. Kepiawan beliau ini salah satunya nampak ketika beliau berkomunikasi dengan bajingan. Beliau memahami dan menggunakan bahasa bajingan juga. Hal ini dilakukan agar dapat menarik simpati para bajingan.

Ketiga, Keselarasan atau kesejatian (Carl Rogers) dan teguh memegang prinsip (Kiai As'ad). Ini mengisyaratkan bahwa seorang terapis harus tampil nyata, yang berarti sejati, terintegrasi, dan otentik selama dalam proses terapi. Ia tampil tanpa kepalsuan, pengalaman batin dan ekspresinya bersesuaian, serta secara terbuka mengungkapkan perasaanperasaan dan sikap-sikap yang muncul dalam hubungan dengan klien. Sedangakan keteguhan Kiai As'ad dalam memegang prinsip juga terealisasi sebagai bentuk pengungkapan perasaan, perasaan maupun sikap yang selama ini beliau yakini. Hal yang baik dikatakan baik, yang benar dikatakan benar, dan yang jelek dikatakan jelek.

Keempat, Perhatian positif tanpa syarat (Carl Rogers) dan Ikhlas dalam beramal/berjuang (Kiai As'ad). Terapis harus memiliki perhatian yang mendalam dan tulus (ikhlas). Dalam artian, perhatian yang diberikan tidak dicampuri oleh evaluasi atau penilaian terhadap perasaan-perasaan, pemikiran-pemikiran, dan tingkah laku klien sebagai baik atau buruk. Ia menerima dan menilai klien secara hangat tanpa menaruh syarat dalam 
penerimaannya itu. Sedangkan pandangan hidup beliau Kiai As'ad terfokus pada perjuangan menegakkan kebenaran dengan tulus ikhlas karena Allah SWT. Ini terbukti ketika usai berjuang fisik melawan penjajah, beliau dipanggil Bung Karno untuk diberi penghargaan berupa jabatan, namun beliau menolak secara halus dan memilih kembali ke pesantren.

\section{b. Perbedaan Konsep Pribadi Konselor menurut Carl Rogers dan nilai Kepribadian dalam Diri Kiai As'ad}

Berdasar hasil telaah, perbedaan konsep nilai pribadi konselor menurut Carl Rogers dan nilai kepribadian dalam diri Kiai As'ad dapat dilihat pada tabel 1.2, dan selanjutnya akan dipaparkan sebagai temuan baru nilai pribadi konselor dalam bimbingan dan konseling Islam yang terintegrasi dalam pribadi seorang Kiai.

Tabel 1.2. Perbedaan Nilai-nilai Pribadi Konselor

\begin{tabular}{|c|c|c|}
\hline \multirow{2}{*}{ No. } & \multicolumn{2}{|c|}{ Nilia-nilai Pribadi Konselor } \\
\hline & Carl Rogers & Kiai As'ad \\
\hline 1. & Objektivitas & - \\
\hline 2. & Menghormati individu & Rendah hati (tawadhu') \\
\hline 3. & Pemahaman diri & - \\
\hline 4. & Pengetahuan psikologis & Piawai berkomunikasi \\
\hline 5. & $\begin{array}{l}\text { Keselarasan atau } \\
\text { kesejatian }\end{array}$ & Teguh memegang prinsip \\
\hline 6. & $\begin{array}{l}\text { Perhatian positif tanpa } \\
\text { syarat }\end{array}$ & $\begin{array}{l}\text { Ikhlas dalam beramal atau } \\
\text { berjuang }\end{array}$ \\
\hline 7. & $\begin{array}{l}\text { Pengertian empatik yang } \\
\text { akurat }\end{array}$ & - \\
\hline 8. & - & Zuhud dan sederhana \\
\hline 9. & - & Pejuang \\
\hline 10. & - & Disiplin waktu dan istiqomah \\
\hline 11. & - & $\begin{array}{l}\text { Suka silaturrahim dan ziarah ke } \\
\text { makam Sunan }\end{array}$ \\
\hline 12. & - & $\begin{array}{l}\text { Hidup mandiri dan menjaga } \\
\text { kebersihan }\end{array}$ \\
\hline 13. & - & $\begin{array}{l}\text { Gemar membangun untuk } \\
\text { kepentingan Agama dan Bangsa }\end{array}$ \\
\hline 14. & - & Mementingkan kepentingan umat \\
\hline 15. & - & Kasih sayang \\
\hline
\end{tabular}

$120 \mid$ JURNAL LISAN AL-HAL 
Perbedaan konsep nilai pribadi konselor menurut Carl Rogers dan nilai kepribadian dalam diri Kiai As'ad terletak pada tigal hal:

1) Objektivitas. Objektivitas dimana termasuk kapasitas simpati yang tidak berlebihan, sikap yang munjukkan keaslian penerimaan dan perhatian, dan pemahaman yang mendalam.

2) Pemahaman diri

Pemahaman diri artinya menerima dirinya sendiri serta sadar diri.

3) Pengertian empatik yang akurat

Konsep ini menyiratkan bahwa terapis dapat memahami perasaanperasaan klien seakan-akan perasaan-perasaan itu merupakan perasaan-perasaannya sendiri, namun tanpa tenggelam di dalamnya. Salah satu tugas utama terapis adalah mengerti secara peka dan akurat pengalaman dan perasaan klien sebagaimana pengalaman dan perasaan itu tampil selama interaksi terjadi dalam proses terapi.

Sedangkan konsep nilai pribadi konselor yang ada pada dalam diri Kiai As'ad yang tidak ada dalam konsep kepribadian konselor menurut Carl Rogers yaitu:

\section{a. Zuhud dan sederhana}

Beliau dikenal sebagai ulama yang lurus dan selalu tampil dalam kesederhanaan, seperti berpakaian, tempat tinggal, dan fasilitas-fasilitas lainnya. Pakaian sehari-hari yang dikenakan yakni sarung, baju piyama warna putih, dan kpyah putih. Dan berpuluh-puluh tahun tinggal di rumah bambu serta beralaskan anyaman tikar tanpa kasur maupun bantal. Hal ini sejalan dengan pendapat Syamsul Arifin mengenai pribadi konselor dalam bimbingan dan konseling Islam bahwa seorang konselor harus memiliki sifat zuhud (menjauhkan diri dari dunia). Konsep ini mirip dengan konsep asketisme dalam teori psikoanalisis. Konsep ini berarti konselor memiliki pertahanan matang untuk meninggalkan kehidupan duniawi dan mendapatkan kesenangan spiritual. ${ }^{20}$

\section{b. Pejuang}

Semangat juang dan keberanian beliau melawan penjajah begitu nampak, mulai dari mengusir penjajah dari Garahan (Jember), hingga turut serta bertempur melawan Belanda di daerah Gedangan (Sidoarjo). Dari keberanian inilah beliau mendapat julukan "macan kurus", karena perawakannya yang tinggi dan kurus. Menjadi pejuang haruslah memiliki

${ }^{20}$ Samsul Arifin, Sang Pelopor: Kisah Tiga Kyai dalam Mengelola Bekas Bajingan, (Surabaya: Salsabila Putra Pratama, 2011), 167. 
mental dan fisik yang kuat. Hal ini selaras dengan pendapat Cavanagh dalam Syamsu Yusuf dan Juntika Nurihsan bahwa salah satu kualitas pribadi konselor yaitu kuat (strength). Ini berarti bahwa kekuatan dan kemampuan konselor sangat penting dalam konseling, sebab dengan itu konseli akan merasa aman. ${ }^{21}$

Selain itu, keberanian tersebaut selaras dengan pendapat Prayitno dan Erman Amti yang mengungkapkan bahwa seorang pembimbing (konselor) perlu juga berani. Pertama, berani memasuki usaha bimbingan dn konseling. Usaha bimbingan dan konseling yang menampilkan pribadipribadi tanpa topeng bukanlah pekerjaan yang mudah. Untuk terjun ke dalam dunia tanpa topeng diperlukan keberanian tertentu. Kedua, berani mengisi usaha bimbingan dan konseling dengan teknik dan materi tertentu. Perlu diingat bahwa usaha bimbingan dan konseling merupakan usaha yang penuh resiko dalam hubungan antarpribadi dan risiko yang berupa kegagalan mengarahkan kemandirian orang yang dibimbing. Tentu saja keberanian yang dimaksud bukanlah berani yang asal berani saja, melainkan disertai dengan kesiapan dalam membuka diri dan kesiapan dalam memperkecil kemungkinan risiko gagal sampai seminimal mungkin. ${ }^{22}$

\section{c. Disiplin waktu dan istiqomah}

Ketika mendapat undangan ceramah atau rapat NU, beliau selalu datang lebih awal atau tepat waktu. Atau dalam pengajian umum yang biasanya masyarakat menunggu penceramah, namun beliau justru menunggu pendengar. Beliau pernah menuturkan bahwa kita harus pandai-pandai menghargai waktu. Selain itu, beliau juga istiqomah dalam melaksankan aktivitasnya. Setiap hari mulai tengah malam beliau selalu mengelilingi pondok. Hal ini sejalan dengan pendapat Depdiknas mengenai standar kompetensi konselor, bahwa seorang konselor dalam menunjukkan integritas dan stabilitas kepribadian yang kuat dapat ditunjukkan dengan berdisiplin dan konsistensi. ${ }^{23}$

\section{d. Suka Silaturrahim dan Ziarah ke Makam Sunan}

Setiap hari beliau bersilaturrahim terutama kepada sanak famili, kenalan dan teman dekat. Silaturrahim berarti membina hubungan kasih

\footnotetext{
${ }^{21}$ Syamsu Yusuf dan Juntika Nurihsan, Landasan Bimbingan dan Konseling (Bandung PT. Remaja Rosdakarya, 2006), 40.

22 Sukardi \& Kusmawati, Proses Bimbingan, 23.

${ }^{23}$ Departemen Pendidikan Nasional, Penataan Pendidikan, 145.

122 JURNAL LISAN AL-HAL
} 
sayang. Hal ini selaras dengan pendapat Cavanagh dalam Syamsu Yusuf dan Juntika Nurihsan bahwa seorang konselor harus memiliki pribadi yang hangat. Dalam artian pribadi yang ramah, penuh perhatian dan memberikan kasih sayang. Konseli yang datang kepada seorang konselor harus disikapi dengan ramah, perhatian dan kasih sayang. Karena ia adalah orang yang sedang membutuhkan rasa hangat dengan cara "sharing" dengan konselor. ${ }^{24}$ Selain itu, Kiai As'ad juga tak henti-hentinya berziarah ke makam-makam sunan, terutama makam sembilan Sunan (Wali Songo). Hal ini biasa beliau lakukan sebelum atau sesudah mengadakan acara imtihan atau Maulid Nabi Muhammad SAW di pondok pesantren.

\section{e. Hidup Mandiri dan Menjaga Kebersihan}

Sikap mandiri beliau miliki sejak beliau masih muda. Beliau mengembara ke berbagai daerah untuk belajar hidup mandiri tanpa bergantung kepada orang tua. Dan beliau juga belajar berdagang sampai ke daerah Asembagus. Hal ini sejalan dengan pendapat Dewa Ketut Sukardi \& Nila Kusmawati bahwa kemandirian konselor dituntut apabila ingin membantu konseli agar dapat mandiri. Penampilan kemandirian dan bobot konselor akan sekaligus menampilkan integritas atau keterpaduan kepribadiannya. Apakah kepribadian konselor benar-benar telah dewasa, matang, stabil, dan terintegrasi secara mantap. ${ }^{25}$ Selain itu, Kiai As'ad juga dikenal sebagai ulama yang sangat memperhatikan kesehatan fisik dan kebersihan lingkungan, terutama kebersihan lingkungan pondok dan kesehatan para santrinya.

\section{f. Gemar Membangun untuk Kepentingan Agama dan Bangsa}

Banyak sekali pondok, masjid dan madrasah yang dibangun atas prakarsa dan bahkan dibangun langsung oleh beliau. Beliau dikenal tak pernah menunda-nunda pekerjaan. Kapan saja ada kesempatan dan bisa dilaksanakan, maka langsung dikerjakan.

\section{g. Sikap Tawadhu' (Rendah Hati) dan Ikhlas}

Tawadhu' dan ikhlas merupakan dua hal yang saling berkaitan. Ikhlas merupakan suatu perbuatan membersihkan dan memurnikan hati, dari sesuatu selain Allah. Implikasi dari sikap ikhlas adalah menimbulkan sikap tawadhu (sikap rendah hati). Dalam melakukan aktivitas dakwah,

\footnotetext{
${ }^{24}$ Yusuf dan Nurihsan, Landasan Bimbingan, 41.

${ }^{25}$ Sukardi \& Kusmawati, Proses Bimbingan, 23.
} 
sikap ikhlas sangat dibutuhkan, sebab ikhlas merupakan landasan diterimanya suatu amal, menjamin keberhasilan, aktivitas akan semakin kokoh, jalan kian membentang, menyingkirkan segala rintangan, serta menyebabkan mendapat taufik dan pertolongan Allah. Hal ini sejalan dengan pendapat Syamsul Arifin bahwa salah satu kepribadian konselor dalam sudut pandang keislaman yaitu ikhlas dan tawadhu' (rendah hati). Konsep ini berarti konselor yang berhasil/ideal adalah mereka yang memiliki respek, penghargaan diri, dan terbuka terhadap perubahan. ${ }^{26}$

\section{h. Mementingkan Kepentingan Umat}

Persoalan mementingkan kepentingan umat tidak boleh diremehkan oleh para juru dakwah. Jika para dai memikirkan dan membantu orang lain, sebagai konsekuensi logisnya, pesan-pesan dahwah yang disampaikan akan didengar dan diperhatikan umat. Hal ini selaras dengan kompetensi konselor dalam mengembangkan pribadi dan profesionalitas secara berkelanjutan pada poin memiliki kesadaran dan komitmen terhadap etika professional bahwa salah satu pribadi konselor yakni mendahulukan kepentingan konseli daripada kepentingan pribadi konselor. ${ }^{27}$

\section{i. Kasih Sayang}

Kasih sayang memiliki dampak yang amat besar dalam mempengaruhi orang lain. Sikap kasih sayang berperan dalam menciptakan kharisma seseorang di mata orang lain. Dalam menaklukkan bajingan, beliau selalu mendahulukan sikap kasih sayangnya daripada sikap kekerasan, walaupun dunia bajingan identik dengan dunia kekerasan. Beliau juga sangat memperhatikan tetangganya yang kurang mampu denga sering diberi bantuan.

Hal ini sejalan dengan pendapat Syamsul Arifin bahwa menjadi konselor harus memiliki pribadi kasih sayang (rahmah). Kasih sayang ditunjukkan kepada murid dalam sehari-hari, baik ketika murid sedang dalam layanannya maupun ketika sudah selesai dari layanannya. Kasih sayang yang diberikan pun mencakup aspek lahiriyah maupun batiniyah. ${ }^{28}$ Selain itu, kasih sayang merupakan salah satu bentuk pribadi konselor yakni pribadi yang hangat seperti yang diungkapkan Cavanagh dalam Syamsu Yusuf dan Juntika Nurihsan, bahwa dalam proses konseling si

${ }^{26}$ Arifin, Sang Pelopor, 167.

${ }^{27}$ Departemen Pendidikan Nasional, Penataan Pendidikan, 146.

${ }^{28}$ Ibid, 163.

$124 \mid$ JURNAL LISAN AL-HAL 
konseli yang datang kepada seorang konselor harus disikapi dengan ramah, perhatian dan kasih sayang. ${ }^{29}$

Berdasar pemaparan dari perbedaan kedua konsep kepribadian, maka dapat ditemukan beberapa nilai kepribadian yang dapat diterapkan konselor yang didapat dalam nilai kepribadian Kiai As'ad, yaitu zuhud dan sederhana, pejuang, disiplin waktu dan istiqomah, suka silaturrahim, hidup mandiri dan menjaga kebersihan, mementingkan kepentingan umat (konseli/klien), dan kasih sayang.

\section{Kesimpulan}

Pembahasan terhadap penemuan dari data-data yang telah dipaparkan, dapat disimpulkan bahwa terdapat persamaan dan perbedaan nilai kepribadian konselor berdasar teori kepribadian konselor Carl Rogers dan nilai kepribadian yang terdapat dalam diri Kiai As'ad sebagai berikut: Pertama, Persamaan konsep nilai kepribadian konselor menurut Carl Rogers dan nilai kepribadian dalam diri Kiai As'ad yaitu: menghormati individu dan rendah hati; pengetahuan psikologis dan piawai berkomunikasi; keselarasan atau kesejatian dan teguh memegang prinsip; dan perhatian positif tanpa syarat dan ikhlas dalam beramaldan berjuang.

Kedua, Perbedaan konsep nilai kepribadian konselor menurut Carl Rogers dan nilai kepribadian dalam diri Kiai As'ad, yaitu: a) Carl Rogers: objektivitas, pemahaman diri dan pengertian empatik yang akurat dan b) Kiai As'ad: zuhud dan sederhana, pejuang, disiplin waktu dan istiqomah, hidup mandiri dan menjaga kebersihan, gemar membangun untuk kepentingan agama dan bangsa, mementingkan kepentingan umat, dan kasih sayang.

\section{DAFTAR PUSTAKA}

Departemen Pendidikan Nasional. Penataan Pendidikan Profesional Konselor dan Layanan Bimbingan dan Konseling dalam Jalur Pendidikan Formal. Jakarta: Dirjendikti, 2008.

Hasan, Samsul A. Sang Pelopor: Kisah Tiga Kiai dalam Mengelola Bekas Bajingan Cet.1. Surabaya: Salsabila Putra Pratama, 2014.

Lestari, Sri. Psikologi Keluarga: Penanaman Nilai dan Penanganan Konflik dalam Keluarga. Jakarta: Kencana, 2012.

Mcloeod, John. Pengantar Konseling: Teori dan Studi Kasus Ed.3, Cet.3. Jakarta: Kencana 2010.

\footnotetext{
${ }^{29}$ Yusuf dan Nurihsan, Landasan Bimbingan dan Konseling, 41.
} 
Palmer, Stephen. (Ed), Konseling dan Psikoterapi Cet.1. Yogyakarta: Pustaka Pelajar, 2011.

Prayitno \& Amti, Erman. Dasar-dasar Bimbingan Konseling. Jakarta: Rineka Cipta, 2004.

Salahudin, Anas. Bimbingan \& Konseling. Bandung: CV Pustaka Setia, 2012.

Shet, N.R. "Values in Search of Identity", Journal of Human Values, Vol. 1, No. 1, 1995.

Sudrajat, Akhmad. "Kualifikasi dan Kompetensi Konselor - Permendiknas No.27 Tahun 2008", dalam https://akhmadsudrajat.wordpress.com/2008/12/16/kualifikasidan-kompetensi--konselor/, (3 Desember 2017).

Sutoyo, Anwar. Bimbingan dan Konseling Islami. Semarang: Widya Karya, 2008.

Walgito, Bimo. Bimbingan dan Penyuluhan di Sekolah. Yogyakarta: Andi Offset, 1989

Yusuf, Syamsu dan Nurihsan, Juntika. Landasan Bimbingan dan Konseling. Bandung: PT. Remaja Rosdakarya, 2006. 